\title{
EUROPEAN CULTURAL POLICY: PRIORITIES AND PRACTICES IN THE FIELD OF CULTURAL HERITAGE
}

\author{
UDC 316.7(4)
}

\section{Jelena Petković}

University of Niš, Faculty of Philosophy, Department of Sociology, Niš, Serbia

\begin{abstract}
By applying a comparative method and analysis of documents, this paper studies the altered position and role of culture as a delicate field of intervention in the field of European integration policies. From that standpoint we approach the sociocultural and anthropological analysis of the basic directions of development in European policy in the fields of culture from the beginning of the process of EU integrations to this day. The aim of the research is to indicate the causes and consequences of increased interest of the European political agenda for the concept of cultural heritage, in particular from the 1970s, with the intention to critically analyze the conceptual interpretations and strategic uses of cultural heritage as part of European cultural policy. For that purpose, the paper provides insight into the basic research findings on the priorities and practices in the field of affirmation of the cultural heritage of Europe, obtained by analyzing and interpreting secondary sources (research papers, numerous internationally accepted documents, various European programs and projects). Conclusions are drawn on the unique contradictoriness in the rhetoric of European political actors, which in the field of cultural heritage balances between European particularism and universalism, as well as the unique strategic shift in European cultural activities from the primary affirmation of the symbolic and social potential of cultural heritage towards the increasingly emphasized use and abuse of its economic dimension.
\end{abstract}

Key words: culture, cultural heritage, European cultural policy, social development

\section{INTRODUCTION}

In the cultural development of Europe, the affirmation of various material and nonmaterial values which have, throughout history, contributed to the progress of civilization, human consciousness and spirit (the heritage of Greek and Roman humanism, Judaism and Christianity, the Renaissance, scientific rationalism, liberal thinking, the industrial revolution, Romanticism, socialist teachings and constitutional democracy, the concept of

Received October 21, 2019 / Accepted November 4, 2019

Corresponding author: Jelena Petković

University of Niš, Faculty of Philosophy, Ćirila i Metodija 2, 18000 Niš, Serbia

E-mail: jelena.petkovic@filfak.ni.ac.rs 
political organization in the form of state-nations, civic values) is quite significant. To no smaller extent, those practices which reflect numerous crisis points and the negation of European humanist ideas and ideals were also realized, and marked European history (imperialism, colonialism, eurocentrism, fascism, Nazism). Thus, along with the numerous cultural specificities and varieties, the peoples of Europe also share certain segments of a common cultural heritage, achievements, values and collective memories, which bind them, but also oblige them to create a new humanism and cultures of peace and progress which are suited to and needed in the current spirit of the times.

It is clear that this is what the ideational creators of unified a Europe had in mind (see Hugo 1849; Kant 1995) when beginning with the $18^{\text {th }}$ century they developed the idea of eternal peace and the creation of an European society whose values would be based precisely in the heritage of the shared European culture, and not on territory as the basis of the ethnic identity of the peoples of Europe, which had been the cause of many wars. Even though the connections between European countries in the first half of the $20^{\text {th }}$ century were initially established based on business, economic and political focus, over the past few decades there has been more and more emphasis on the cultural dimension of the unification and connection between countries within the European Union. Contrary to the economic, legal and political factors (the euro as a shared currency, the adaptation of the legislatures of the individual counties to the Acquis Communautaire of the EU and the relativization of state borders among the EU members) which have especially emphasized unification effects, the process of EU integrations could from the position of culturologists and sociologists of culture be interpreted differently. From this perspective, European integration can be understood as a large experiment involving a dialogue among cultures, as a more or less successful attempt to, with a critical awareness of a shared cultural heritage, preserve differences and turn them into shared values which will contribute to general social development and progress. These are at the same time some of the basic goals and priorities in the areas where contemporary European cultural policy is active, and whose basic features can be seen in numerous documents, programs and activities of the European Union and the Council of Europe.

The intention of the author of this paper is to, by applying a comparative method and document analysis in the introductory part of the text, first analyze the changes in the positions and roles of culture from a rather marginalized one to one of the crucial and certainly sensitive fields of intervention in European integration policies. This will represent the basis on which in the remainder of this paper, the basic characteristics and direction of development of the European cultural policy from the beginning of the process of EU integrations until today will be outlined, from a sociocultural and anthropological perspective. A special critical overview will be provided of the increased interest in European political agendas for the concept of cultural heritage, starting from the 1920s, in order to indicate the conceptual shift from cultural integration towards sociocultural diversity, and to explain the unique contradictoriness of European cultural activities and political rhetoric in the field of cultural heritage balances between European particularism and universalism. For that purpose, the paper provides insight into the basic research findings on the priorities and practices in the field of affirmation of the cultural heritage of Europe, obtained by analyzing and interpreting secondary sources of data (scientific publications, numerous internationally accepted documents, reports on the realized activities as part of various European institutions, programs and projects). 


\section{The Position AND Role of Culture In the ConteXt of EUROPEAN INTEGRATIONS}

A supranational economic-political community of European countries and citizens emerged in 1951 with the founding of the European Coal and Steel Community. As a result of the initial process of cooperation, the governments of six western European countries ${ }^{1}$ also took control over the shared management of the basic raw materials needed for heavy industry which were, among other things, used for the production of weapons. In addition to an economic, this also had a significant symbolic significance - following various conflicts throughout history, especially the atrocities caused by World War Two, this represented an attempt to prevent new confrontations and wars between the peoples of Europe. Already in 1957, the signing of the Treaty of Rome marked the beginning of a broader process of integrations by the creation of the European Economic Community. From it emerged the contemporary European Union with the ratification of the Maastricht Treaty which entered into force on November 1, 1993. Thus, we should bear in mind that the European Community emerged from and developed based on the needs of the economic-political interests of large European countries, that is, that the primary basis for the European integrations of European countries was the field of heavy industry and the development of free trade. Thus, culture initially was not a field which attracted the attention of the officials of the European Economic Community, and so it was mostly delegated to the Council of Europe and UNESCO. This is confirmed by the fact that in the Treaty of Rome from 1957, the word culture was mentioned only once, in the preamble of the treaty, where it was interpreted rather generally as a factor which can contribute to the unity of peoples and the improvement of the social and cultural development of the member countries. It was only in 1992, with the signing of the Maastricht Treaty (Article 128), that is, the Treaty on the European Union (Article 151) that culture was written into the founding normative documents, which institutionalized cultural programs and activities, and the significance of culture in European interactions formally recognized. ${ }^{2}$

We can say with certainty that culture has been an especially sensitive field of intervention in European integration policy. Due to the numerous cultural diversity and specificities of the European peoples (languages, religions, customs, myths, national heroes, folklore, architectural styles, culinary specialties, etc.), it emerged that national culture was a painful issue for all the European countries. Namely, the peoples of Europe, based on their national cultural policies, attempted to preserve and develop their culture and tradition by resisting cultural uniformization in any form of cultural supremacy. That is why certain countries were careful to limit the competencies of the EU in the field of culture, experiencing them as a possible threat to their own cultural identity. Bearing this in mind, in the final version of the Treaty on the EU, the use of concepts such as European culture and European cultural identity was avoided (so as not to negate or question the issue of the context of national culture and cultural heritage and the identity of the various peoples of Europe), and only at the level of recommendations was there any word of the contribution to the development of culture and cultural cooperation between the member countries, as well as between European and nonEuropean countries.

\footnotetext{
${ }^{1}$ This includes Belgium, France, the Federal Republic of Germany, Italy, Luxembourg and Holland, which are considered the founding states of the European Union, which today numbers 28 member states.

${ }^{2}$ For more details on the basic concepts and theories of the emergence of a unified Europe and Europeanization following World War II, as well as the European integrations of Serbia, please see Brujić 2016.
} 
Over the position of culture in European integration processes changed, and today support for the emergence of a single Europe is based more and more explicitly on the acknowledgement of the importance of culture and the role of cultural heritage, contemporary creativity, and exchange within the contemporary processes of development. Today's policy makers and development strategy makers within the EU attempt to rely on a holistic approach in designing a kind of balance between growth and development, in the desire to achieve at the same time economically measurable results - influx of investments, hiring and increase in consumption - as well as culturally and socially relevant results - preservation of the peace and safety, protection and promotion of cultural heritage, social cohesion, improvement of the quality of the living environment, democracy in the approach to the highest cultural (humane) values and civic freedoms (Sen 1999). For example, over the past few years, there was special encouragement for the development of cultural and creative sectors in Europe since they were proven to contribute to economic growth, considering that they make up 4,5\% of the European GNP, and hire approximately $3,8 \%$ of the EU workforce, which is approximately 8,5 million citizens (European Commission 2017, 3). In addition, it was indicated that in times of economic crisis the cultural and creative sectors in Europe are far more resistant than other sectors, that they significantly contribute to innovations, the development of skills and the European urban regeneration, at the same time providing a positive influence on other sectors such as tourism, information and communication technologies, and intercultural education. We should also not forget that Europe today is a kind of cultural community of citizens enriched by a broad spectrum of various national (European and extra-European) influences, which is directly reflected on the quality of daily life of a great many people. Precisely because formally there is a desire, with more or less factive likelihood, to shape and organize Europe as a desirable place to live and work for people from various cultural environments, who are culturally aware and engaged, creative and critically active, with the sensitivity needed for a life together, mutual intercultural communication and cooperation.

In the context of contemporary social challenges, however, we get the impression that the economy and politics are less and less frequently able to preserve the sense of European community (especially bearing in mind the problematic issues of Brexit - the current process of withdrawal of the United Kingdom from the EU), and contribute increasingly more to the instability and lack of security of European citizens. The world economic crisis shook Europe as well, while the migrant crisis of the past few years contributed to rightwing political parties and leaders gaining power in certain European countries, who often quite openly represent nationalist and populist aspirations (mostly due to islamophobia and the differently perceived accumulated and unsolved problems related to the reception and status of large numbers of migrants, especially Muslims from extra-European countries). It is clear that multiculturalism in Europe as a concept of cultural policy has failed, and that today is undergoing a discursive and practical reevaluation and estimation, which leaves open the question as to whether this will imply some new and different political solutions for the regulation of the increasing cultural diversity of European societies (Milenković 2014 ${ }^{3}$; Petković 2018). This is important, considering that the segment of European heritage which was connected to the previous colonial Eurocentric arrogance requires that Europe reevaluate its interpretations and relations towards other non-European peoples and to more

\footnotetext{
${ }^{3}$ In the cited source it is possible to find out in more detail about why multiculturalism is legally and politically problematic, why the outcomes of multicultural policies were unsuccessful and what contributed to the pessimism of the contemporary anthropology of multiculturalism.
} 
decisively open up towards the pluralism of world cultures (Moren 1989, 144). In any case, we could say that today's European Union is far from the perfect ideals of its ideational creators, as much as it is from the chaos of imperfection which its critics ascribe to it with blatant apocalyptic premonitions.

\section{The DeVElopment of European Cultural Policy}

Up until the end of the 1970s, culture and cultural policy were, as fields of activity of the European Union, present indirectly through the application of the Treaty of Romein the field of culture, which primarily referred to the economic, work and social rights of the workers, that is, artists and creators in the cultural sector (for more details see Stojković 1995, 29-33). With the aim of improving cultural activities within the European framework, in 1954 a new European cultural foundation was established. That same year in Paris, the Council of European adopted the European Cultural Convention (Council of Europe 1954), and then founded the Council for Cultural Cooperation, whose aim was to contribute to the harmonization of activities of European countries by encouraging cultural activities with a shared, European interest. In addition, the purpose of the aforementioned convention was the development of a mutual understanding among the peoples of Europe and the mutual respect for their cultural diversity. The focus was on promoting national contributions to the shared cultural heritage of Europe, as well as on respecting the universal sociocultural values, and especially on encouraging the study of language, history and civilizations of the countries which had adopted it. Due to a changed understanding of culture and social development on a global level, ${ }^{4} 1984$ saw the adoption of the European Declaration on Cultural Objectives (Council of Europe 1984), whose significance can in particular be seen in the affirmation of not only the material, but also the non-material cultural heritage of the peoples of Europe, as well as the human rights and liberties of individuals in the field of culture. A more important watershed turning point in the attitude of the European Union towards culture took place in 1988. At this point, a new document was adopted, the New incentives for culture in the European Union, which, starting from the standpoint of European integrations, at the same time both broadly and precisely cited the basic directions and priorities of the cultural policy of the Union. They included: 1. The creation of a European cultural space; 2. The improvement of the European audio-visual industry; 3. The facilitation of access to cultural heritage; 4. Connecting with the culture of countries outside of the EC. (Dragićević Šešić and Stojković 2011, 300).

\footnotetext{
${ }^{4}$ The modern concept of culture has shifted from the ontological plane to the social level, that is, from individuality to the concept of collective mentality. In the pluralism of cultural models, contemporary understanding of culture begins, especially in the second half of the $20^{\text {th }}$ century, to be linked to collective identities (national, regional, continental, religious, gender, sexual), which in an age of globalization and in the context of multicultural societies have become more numerous and important than ever before. At the same time, it is worth remembering that the problems of identity in Europe have become complex, especially during and following the turbulent and significant social changes generated by the fall of communism, the end of the Cold War, the unification of Germany, the disintegration of the former socialist countries (SSSR, SFRJ, CSSP), as well as the increase in the number refugees, immigrants, the mobility of knowledge and workforce throughout the European continent.
} 
With the founding of the European Union, numerous programs and project activities marked the beginning of a more significant and effective nurturing and improvement both of national and regional cultural diversity, and also the promotion of a shared cultural heritage, as well as encouragement for cultural cooperation, creation, and non-commercial cultural exchange. Even though the members of the EU have sole jurisdiction in the field of cultural policy, and thus over their own means of regulating the development of culture and the audio-visual media in accordance with their own cultural, social, economic and political characteristics, the role of the EU is to contribute to these endeavors, to offer encouragement and guidelines for cooperation, and to support and complement the activities of the member states. With that aim in mind, the European Commission in 2004 proposed a cultural agenda of the EU, and the First European Agenda for Culture was adopted in 2007 (European Commission 2007). These activities supported the affirmation of the so-called "open method of coordination", a specific form of managing culture which is based on the voluntary cooperation between the EU member states. A crucial characteristic of contemporary European policy lies in the fact that there is no desire for complete standardization and unification in the cultural sector ${ }^{5}$, but instead for the creation of a favorable political, normative, financial and logistic framework for the realization of cooperation in culture among the member states and the institutions of the EU involved in culture, as well as encouragement for cooperation with individual countries outside the EU, regional and international cultural organizations, networks and other actors involved in culture (The Council of Europe, UNESCO, Europa Nostra, etc.).

European cultural policy in various phases of European integration was focused on the realization of different goals in the domain of culture as part of numerous strategies of development. In the dominant conviction that art and culture are the way to personal enlightenment and spiritualization, in the 1950s the cultural-political agenda was aimed mostly at the ideals of enlightenment. This primarily initiated attempts to facilitate the access of various social groups to cultural heritage, the arts and elite, high culture. Great attention in certain European countries was dedicated to the building of classical cultural institutions (museums, theatres, galleries, concert halls) which were the main means of support for these kinds of cultural policies.

The 1960s saw the development of the concepts of democratization and decentralization of culture. The dominant idea was one of greater availability of culture (primarily elite) by means of free theatre performances, travelling movie theaters, the erection of culture halls in smaller towns, as well as the equal cultural development of the town and country. Providing an overview of the developmental characteristics within the socio-cultural policy in Europe following World War Two, Scott-Hansen (1998) referred to this period as the social period of European cultural policies. This is predominantly because of the focus on the equation between creative and receptive conditions for all, especially vulnerable social groups such as women, children, people living in rural areas, homosexuals and immigrants.

Budget funds for culture in the 1970s were large in almost all the countries of Europe, which coincides with the increase in awareness of political actors of the importance of culture. At this time, the European community began specific activities in the field of culture with the

\footnotetext{
${ }^{5}$ Without delving into the content of artistic and scientific activities, a unified legislature is used to intervene in certain cases of protection of copyright, intellectual property, cultural goods and practices. In order to facilitate the approach to cultural heritage, publishing and library standards are made uniform, technical standards are prescribed in the field of audio visual and computer science industry (as was the case in the 1990s with high resolution television, and today with the digitalization of cultural heritage and creativity).
} 
aim of providing content for the European identity and encouraging identification of the citizens in the context of the European project. Thus through the agenda of the Union in 1974 the concept of European cultural heritage was affirmed, as were the attempts at a cognitive and affective basis for the European identity outside of abstract political categories and principles. Thus, actually, more significant changes began within the European cultural policy of the discourse and transformations of practices which referred to the segment of European cultural heritage, and which were primarily in the function of the socio-cultural integration of European citizens (Calligaro 2014, 62; Patel 2012).

In the 1980s, the numerous projects in the European Commission and activities of the Council of Europe continued the attempts at constituting and strengthening the awareness of "Europeans" regarding their cultural supranational identity, as well as the establishment of European citizenship, which is in essence deeply connected to issues of "European culture" and the concept of cultural heritage. More evidence for this can be found in the project "People's Europe", which the European Commission developed and carried out during the 1908s. Even though this project initially was set more broadly, its main emphasis was on the shared European symbols, which were established at the time and much later, such as the European passport, flag, national anthem, postage stamps with European insignia, European drivers' licenses, European television, universities, European club sports competitions, European film festivals and the like, so that the citizens of various European countries could finally think of themselves as Europeans (Shore 1993; Hudson 2000; Brujić 2016, 40). On the other hand, at this time a shift occurred in the European cultural policy from the "democratization of culture" to "cultural democracy". Thus began the more significant affirmation of the concept whose ideas support the availability of shared cultural heritage to all the citizens of Europe, who will, respecting the rights and freedoms of others and the freedoms of people, be able to interpret this heritage, popularize it and protect it in accordance with their own cultural choices and sensibility, as a kind of right to freely take part in the cultural life of the community. The focus thus significantly shifted from cultural consumption to the cultural initiative and active participation in the protection and promotion of cultural heritage. The concept of heritage at this time as a part of numerous cultural initiatives and activities remained a symbol of European high culture and served to defend local cultural diversity in relation to the possible effects of homogenization as part of the European integration process. ${ }^{6}$

For the past few decades, the European Commission, as part of the development of the cultural policy of the EU, has been carrying out numerous programs of support meant for culture. The first generation of cultural programs was developed between 1996 and 1999: Kaleidoscope - meant for the realization of cooperation as part of artistic and cultural activities; Ariane - dedicated to books and the culture of reading and Raphael dedicated to cultural heritage. The second generation of cultural programs was developed after 2000: Culture 2000 - meant for the promotion of culture and cultural heritage which were common to all the people in Europe; Culture (2007-2013) - whose key role was the promotion and protection of European cultural and linguistic diversity, shared cultural

\footnotetext{
${ }^{6}$ By illustrating attempts at the defense of the local cultural heritage at that time in Europe, Branimir Stojković cites the translation of works of literature and providing titles for movies important for European culture from languages which are used by a relatively small number of European citizens (Greek, Swedish, Dutch), as well as activities meant to protect, conserve and renew architectural wholes (the Parthenon in Athens, the Doge's Palace in Venice) which are of crucial importance not only for individual national cultures, but for the shared European cultural heritage (Stojković 1995, 35).
} 
heritage and support for the transborder, cross-sector cultural cooperation between cultural workers and institutions; Creative Europe -a current program which promotes the economic dimension of culture and cultural heritage, supports the cultural and creative industries, the strengthening of growth and employment in the sector of culture, and the contribution of culture to the social development.

As part of the aforementioned program activities, especially from the mid-1990s, European policy in the field of culture also recognizes as its own important goal the provision of support to the development of intercultural competencies of citizens, which includes dialogue, exchange and cooperation between the members of various ethnic, linguistic and culturological groups. The conceptual shift in European cultural policy from cultural integration towards sociocultural diversity, which at this time was already quite obvious, was conditioned by at least two mutually related facts. First and foremost, despite the achieved significant success in the field of legal, political and economic integration, it turned out that the project of constructing and strengthening the European (cultural) identity among the citizens of Europe proved not to be so easy, successful and useful. Ivana Gačanović is of the opinion that the problems which are emerging from a tendency towards constructing "European integrity" are primarily conditioned by inadequate conceptions of "identity", "culture", "community" in European institutions, policies and agendas. At the same time, the author indicates that the idea of a "European identity" actually represents an amalgam of non-consistent thoughts, according to which it is envisioned as a supranational identity based on a "shared European heritage" but also the principle of human rights and respect for cultural diversity (Gačanović 2009, 9-10).

On the other hand, the conceptual shift in European cultural policy can also be explained as a consequence of the inevitability of facing an increasingly broader range of cultural diversity in Europe and the possible political instrumentalization of various cultural identities. Namely, cultural diversity in Europe has expanded from the national level to the subnational context, due to the global migratory courses and increased settling of nonEuropean population, who bring with them the specificities of their own cultural heritage. Therefore, previous (it turns out unsuccessful) attempts at creating a European cultural identity on the one hand, along with a nurturing of national identities on the other, begins gradually to be replaced with the simultaneous arguments in favor of cultural diversity and a shared European culture. It is clear, however, that the achievement of unity in diversity and management of sociocultural diversity is a great challenge for contemporary European political platforms and actors, as well as for the everyday life of the citizens of Europe. It turns out that cultural diversity often generates problems and conflict which emerge especially in the context of denying various minority rights in the field of culture in situations when the communities differently identify, interpret or add contradictory values to the same cultural heritage, or when minority populations do not experience the cultural heritage of the majority as theirs and vice versa (for more details see Gavrilović, 2011). Therefore we have the recommendation of the European Union that cultural policy should be developed contextually (by taking into consideration traditional, historic, contemporary social and cultural specificities) at the lowest possible level: at the level of the region, member countries and local communities. Especially with the adoption of incentives for the development of the culture and cultural heritage of all citizens and the realization of their cultural rights, with the formulation of integrated strategies, and simultaneous relinquishing of complete unification of legal regulations and guidelines in the domain of culture. These attempts are a confirmation of the assessments of certain authors that the crucial nature of cultural issues 
and the importance of identity policy of the EU may be a deciding factor in the continuation of integration processes in Europe (Gačanović 2009; Shore and Abélès 2004). ${ }^{7}$

\subsection{The concept of cultural heritage and European cultural policy}

The concept of cultural heritage began to develop at the end of the $19^{\text {th }}$ century in post-revolutionary France. At the time throughout Europe there began a more significant affirmation of a national heritage which democratizes what had previously belonged only to the elites. ${ }^{8}$ The ideational and legal foundations of national policies which refer to the protection, preservation and improvement of their cultural heritage are put in place. In the European cultural policy, the concept of cultural heritage was affirmed more significantly beginning with the 1970s, when the "rise of heritage" began (Hafstein 2012, 501-503).

Cultural heritage is determined as "a group of resources inherited from the past which people identify, independently of ownership, as a reflection and expression of their constantly evolving values, beliefs, knowledge and traditions. It includes all aspects of the environment resulting from the interaction between people and places through time" (Council of Europe 2005, 2). Despite the fact that it represents a segment of the traditional component of culture, it is clear that cultural heritage plays an important role in contemporary development plans and strategies of European integration processes, as in the plans and visions for a European future. Therefore heritage is a topic not only of cultural policy but also of other public policies of the EU, such as those in the sphere of education, tourism, social cohesion, economy, regional and urban development, the digital agenda, etc. Bearing in mind such a holistic approach to cross-sector cooperation, European cultural policy has clearly defined goals in the field of research, protection and the use of cultural heritage. High priority goals include strengthening awareness, legal and institutional frameworks and the professional capacities for the stable, reliable and effective care of cultural heritage, the use of heritage as a potentially sustainable (social, economic, ecological and cultural) development, its recognition, research and evaluation, as well as protection and presentation and inclusion of heritage in contemporary courses of life especially through the development of an European digital platform for cultural heritage (Council of Europe 2018, 9).

The realization of these goals is connected with the attempts to preserve and develop specific characteristics of the material, non-material and digital cultural heritage of various peoples, as well as the natural heritage of various areas, but to no lesser extent, of universal human values as values of culture in general. The starting point is that significant cultural achievements from various historical epochs (such as philosophical heritage and building heritage from antiquity, medieval cathedrals, churches and monasteries, renaissance artwork, baroque princely palaces and gardens, industrial facilities, folklore, crafts,

\footnotetext{
${ }^{7}$ For more details on the definition of culture and cultural heritage in European institutions and their importance in the context of European integrations, as well as on the cultural policy of the EU and the cultural programs of the European Commission, please see the following sources, listed in alphabetical order: Brujić 2016; Gačanović 2009; Gielen 2015; Gordon 2007; Hafstein 2012; Hudson 2000; McDonald 1996, 1999; Milenković 2014, 2016; Nic Craith 2008, 2012; Sassatteli 2002; Shore 1993, 2006; Shore and Abélès 2004; Zikic 2013.

${ }^{8}$ In several European countries at that time museums of art, science and technology were being opened up, meant for the wider pubic. The idea of shared cultural heritage conveys the goods and rights of princes and prelates, magnates and merchants (Lowenthal 1998, 60) to the wider public, or, as it is presented in the context of the French symbolism it opens up the doors of the Louvre to the mass of people outside in the streets (Hafstein 2012, 505).
} 
language, literature, music, movies and other arts) even though they belong to a certain town, village, country, region, as well as certain individuals and/or communities, also represent the shared cultural heritage of Europe, and also the entire world. Therefore, as part of the European cultural policy the attitude that cares for our shared heritage is our shared mission and responsibility is affirmed. Of course, care for cultural heritage is not only care for monuments and sites, and so the basis of the extended and transversal concept of cultural heritage should include people and human values such as philanthropy and empathy, for example, which represent important principles of culture and which are today slightly forgotten values of the cultural heritage of mankind. ${ }^{9}$ Accordingly, Milenković states that even though most authors point out the instrumental character of the protection of cultural heritage in favor of state, ethnic and the interests of political and economic elites, there are also those, as indicated by Brumman, who do not neglect its creative and antihegemonic aspects, only arguing in favor of a balanced approach which would exclude demonization and glorification (Milenković 2016, 15; see Brumman 2015, 414).

Generally speaking, European institutions and international organizations have mobilized the concept of cultural heritage in order to emphasize that the diverse and specific cultural expressions can be assigned universal values. This is evident in numerous internationally acknowledged documents, conventions and charters. At the general conference of UNESCO in Paris in 1972, the international Convention Concerning the Protection of the World Cultural and Natural Heritage was adopted (UNESCO 1972), and soon after that, as part of the pioneer work of the Council of Europe in the field of cultural heritage, 1975 was declared the European Architectural Heritage Year. It resulted in the adoption of the European Charter of the Architectural Heritage (Council of Europe 1975), which represents one of the first international documents whose importance is primarily viewed in the establishment of a set of principles for the preservation and promotion of cultural heritage in the development plans, that is, monuments and sites in spatial and urban planning. UNESCO has also recognized the importance of intangible cultural heritage, and set before the international community the important and complex task of its preservation and affirmation, adopting in 2003 Convention for the Safeguarding of the Intangible Cultural Heritage (UNESCO 2018). ${ }^{10}$ The Convention or the Council of Europe Framework Convention on the Value of Cultural Heritage for Society (known as the Faro convention because of the Portuguese city Faro in which it was signed) is considered a deciding moment in legal regulation, understanding and emphasis of the role of cultural heritage in Europe, because it predicts the instruments for strengthening awareness of universal values and the importance of cultural heritage, pointing out its important aspects

\footnotetext{
${ }^{9}$ The foundation of these claims was confirmed during a recent event when on April 15, 2019, the cathedral of Notre Dame in Paris caught on fire. The news of the fire and the danger facing such a gem not only of French but also of the European and cultural heritage spread so fast that international activities for collecting funds to renew the cathedral were immediately underway. This action united wealthy French families, the most widely known companies and organizations in the world, as well as governments of numerous countries in the desire to donate funds to contribute to the renewal of this edifice. In only four days, one billion euros was collected. This, however, promoted the rage of the homeless and poor citizens who are struggling against social injustice, activists of the Yellow vest movement in France. They believe that this tragic event actually just emphasized the lack of critical social empathy, pointing out the paradox of contemporary society founded on neoliberal capitalism, which cannot generate solidary towards an increasingly greater number of the poor, deprived of power and surviving on the bare minimum. See the article by: Mattia, 2019.

${ }^{10}$ Miloš Milenković promotes the thesis that the UNESCO system of preserving cultural heritage can be considered the greatest peacetime project of a cultural nature in recent history, which makes it especially worthy of attention in our society and to our academic and intellectual public (Milenković 2016, 10).
} 
related to human rights and democracy. The most recent action plan which is used to regulate the field of cultural heritage as part of European cultural policy is the European Heritage Strategy for the 21st Century (Council of Europe 2018). The aim of this document is to encourage and facilitate the application of various conventions which refer to the concept of cultural heritage, relying on a just and unified approach to heritage and its management, as well as the possibilities which stem from the digitalization of cultural heritage.

Increased interest in the concept of cultural heritage as part of the European political platform, beginning with the 1970s, resulted in an initiative to name 2018 the year of European cultural heritage. With the primary intention of emphasizing the importance of European heritage, to support and strengthen the sense of belonging to the European cultural space, numerous events were realized, as were programs and activities in order to encourage the exchange of shared history and diverse European cultural heritage. The EU has financially and logistically supported numerous projects dedicated to the realization of various goals in the field of cultural heritage, such as the exchange of experience and innovative ideas on the protection and promotion of heritage as a shared cultural, artistic, scientific, economic and emotional resource. ${ }^{11}$

\section{A CRitical OVERVIEW OF THE CONCEPT OF CUltural HeRitage WITHIN EUROPEAN CULTURAL POLICY}

Bearing in mind the development of the concept of cultural heritage as part of the European cultural policy beginning from the 1970s, to the end of the twentieth century (including, thus, the first generation of support programs of the European Commission meant for culture), it is possible to note that increased attention was focused on the promotion and protection of cultural heritage primarily in the context of the affirmation of its symbolic and social potential. This includes the recognition of the importance and activation of the role of cultural heritage in the construction of a cohesive society and collective identity of European citizens, affective attachment for the European integration project and the strengthening of its legitimacy, in which certain theoreticians (Tsaliki 2007, Sassatelli 2009) see the primary goal of European cultural policy. Chris Shore, the author of pioneer studies on the cultural policy of the EU, considers that this policy represents the instrumentalization of culture meant for the creation of European citizens, in a project of social engineering which uneasily reminds us of other failed modernist ideologies of the $20^{\text {th }}$ century (Shore 2006,21 ). The critical pessimism of these evaluations, unfortunately, is not unfounded in contemporary European social reality, since despite the spreading of European rationality and the idea of community, what is at work are implications of failure of several decades of attempts at building a shared European identity and the crisis of crucial European values. In political rhetoric, minority and immigrant communities are often blamed for the failure of multicultural policies in European societies, new types of

\footnotetext{
${ }^{11}$ To illustrate, in 2018, more than 11.700 projects were realized in 37 countries, which were given the official label of the European year of cultural heritage and in whose realization more than 6.2 million people participated (Europa EU 2018). An interesting fact is that for this purpose, a budget of 8 million euros was set aside, where only as part of the Creative Europe program, 5 million euros were donated to finance 29 cross-border projects of collaboration, which connected organizations and actors in culture from various European countries, encouraging synergy between cultural heritage and contemporary creativity (European Commission 2017).
} 
nationalism and separatism are growing everywhere, cultural identifications are increasingly encouraged by xenophobia and burdened by irrational conflicts.

On the other hand, interest in European political agendas for cultural heritage which was affirmed in the second generation of cultural programs developed from 2000 to this day, is mostly the consequence of newly acquired evaluations of cultural practices and objects in the sense of their usefulness for economic purposes, contribution to economic development, strengthening of growth and increase in employment (Hafstein 2012, 503). Considering, therefore, that the concept of cultural heritage had a strong economic potential, it was additionally relativized by means of the market, which was focused on the issue of how the past could be packaged, presented and consumed in a new way (Nic Craith 2012, 13). Even though the social and symbolic dimensions of cultural heritage were not fully marginalized, critics of the neoliberal economy were prone to stating that what is at work is the "economic instrumentalization and commercialization of culture" as part of the European political platform, which to a certain extent can be interpreted as a kind of strategy of the EU for adapting to the global world in which we find increased domination of market forces (Bruell 2013). Actually, despite the connection between cultures and the strengthening of interaction, the global market, the cultural industry and audiovisual media industry contribute to the realization of the monopoly and expressed domination of the most developed and richest countries in the world. As early as the 1980s, this initiated a specific discussion of the dignitaries of the European Union in which there were concerned warnings of the danger facing European cultural heritage and creation, under the influence of the Americanization of the European culture. ${ }^{12}$ Led by such concerns, the policy dictators at the time were spoke in favor of the necessity of protecting and promoting European cultural heritage, among other things, through a unique European market of satellite television programs and the introduction of obligatory quotas of programs with a European origin. However, this type of possible interventionism was received with ambivalent reviews of the heads of Europe at the time, since many explained their lack of readiness to support these kinds of activities and initiatives by the fact that during the struggle against American cultural imperialism, the hegemonistic concept of the European cultural exclusivity will actually be affirmed.

Activities in the field of cultural heritage and the rhetoric of the creators of European policy, developed on various levels and over various periods of time, were thus to a certain extent contradictory. When it was time to strengthen the sense of European social identity and the identification of the citizens with the project of European integrations, European politicians condemned the monopoly of the state-nations over cultural goods and traditions and referred to their universal values. By analyzing the symbols which were used in the "People's Europe" project to awaken the European identity, Shore noted that for the construction of a "new Europe" within the first cultural initiatives of European institutions, cultural features of national identity were used (which the creators of nineteenth century national states used to construct a sense of national belonging), even though they at the same

\footnotetext{
${ }^{12}$ During the last decade of the $20^{\text {th }}$ century, $80 \%$ of the world's trade in music products was controlled by four large multinational companies, only three countries (the US, England and Germany) owned $47 \%$ of the total export of books, while $50 \%$ of all the companies in the world involved in cultural products and series had headquarters in the US (according to: Vrgoč 2003). Also, of all the audiovisual content, which at the time was broadcast in the countries of the European Union, as much as 57\% was American in origin, only $9 \%$ of it French, $8 \%$ British, 5\% German, $2 \%$ Italian, while the part of the cultural content of the remaining countries of the EU in broadcast programs was almost negligible (Stojković 1995, 14).
} 
time required the abolishment of the sovereign national state and identification with it (Shore 1993, 787 according to Gačanović 2009, 19). Viewed from the current standpoint, we could say that the insufficient success of this and similar projects for the emergence of a shared European identity (European symbols were merely an instrument in the possible achievement of this goal), has proven that the rather optimistic thoughts on a shared European culture in a Europe which was in terms of culture defined as a plurality (McDonald 2005, 4), were overstated and overambitious. On the other hand, the initiatives of the EU as part of the supranational cultural policy attempted to mark out an imagined community which is represented by a specific, shared, and in a certain sense homogenous cultural heritage of Europe. Thus certain antinomies of cultural policy could be viewed in the simultaneous effort for something that is universal (the model of perception of European cultural diversity in the context of universal values) and particular (overstatement of the special nature of the European civilization and shared European cultural heritage where European isolationism was and today still is, though a formally unwanted, potential danger). This supports the attitudes of numerous theoreticians who consider that EU actors used cultural heritage in order to found an integrative political project in the shared identity, walking the sharp edge between universalism and European particularism (Calligaro 2014, 61-62).

\section{CONCLUSION}

Generally speaking, European policy in the field of culture was designed in such a way that a series of recommendations, projects and practical activities work on the preservation, spreading and development of culture in Europe, encouraging cultural cooperation, diversity and a sense of shared cultural heritage. Even though cultural development, promotion and protection of cultural heritage are in the domain of national, regional and local authorities and legal regulations, the role of the European Union and the Council of Europe is to help, complete and harmonize the activities of European counties in the preservation and promotion of European cultural heritage. Thus, there should be no contradiction between national, supranational and subnational responsibilities regarding cultural heritage. Actually, the goal is to achieve their cooperation and establish legal regulations for the protection and promotion of cultural heritage, compiled through numerous local narratives which together make up the history and culture of all of Europe. Considering that Europe of today is a mosaic of various cultural worlds and values, accumulated over various periods of time and in various spaces, European cultural policy is focused on the development of a strategic approach and internationally compatible standards which have to do with the study, preservation, valuation, popularization and safety of a shared cultural heritage of Europe.

Even though the unification of Europe was initially economically and politically motivated, it would seem that the need for European policy to affirm a cultural dimension of development emerged precisely at a time of increased geopolitical divisions, social and economic crises and instability of the European integration projects. Understanding that the European Union is not an affectively liberated economic and political project (organized only "from above" by European officials and diplomats), but necessarily a project of the very European citizens (a general and at the same time subjective context of shared belonging encouraged "from above"), European officials have dedicated themselves to the legitimization and sensibilization of the European integration projects toward cultural orientations. For that purpose, the concept of cultural heritage has been mobilized more 
significantly, along with its social, cohesive and economic potential. Earlier attempts at realizing European identity through a shared European cultural heritage and European symbols, on the one hand, with a nurturing of national identities on the other, due to the increased settlement of non-European populations in the countries of Europe are slowly beginning to be replaced by formally complementary, although slightly confusing and insufficiently conceptually clear, simultaneous advocacy for cultural diversity and shared European culture - unity in diversity.

In the culturally complex social reality of Europe, however, a successful shared model of the European identity has still not emerged, nor has a cross-state agreement been achieved regarding the constitutive elements of shared European cultural heritage. Indicating that there is conceptual confusion in determining European integration (bureaucratic regulations, intergovernmental agreements, economic projects and/or cultural concepts), as well as numerous differences in the interpretation of the concept of "heritage" within various European languages whose analysis was carried out, Nic Craith asks the question of how it is at all possible to define "the shared cultural heritage of Europe" (Nic Craith 2012, 22). Certain authors, however, have drawn a conclusion regarding how the construction of the unification of Europe which relies on European cultural identity and European citizens does not have as its aim to destroy the national state, but instead to protect Europe from nonEuropean Others (Krstić 2011, 69), such as the US, Japan, South-East Europe, Muslim countries. These evaluations speak in favor of the fact that cultural determinants and implications for a unified Europe are clearly complementary and deeply dependent not only on the intra-European but also on the global political, economic and safety circumstances.

The conceptual development of European cultural policy from cultural integration toward socio-cultural diversity was accompanied by certain antinomies in the priorities and practices of European cultural policy, which often balanced between universalism and European particularism. Therefore, we can conclude that the call for a shared past, a simultaneously nationally diverse and civilizationally unified European cultural heritage, serves to strengthen unity and the affective bonding of citizens to the project of European integrations, with attempts made at a critically based humanist (de)construction of the contemporary collective identity of Europeans, but also a demarcation of sorts in relation to non-European Others, as well as an emphasized strategic use of the social, and increasingly more so the economic dimension and usefulness of European cultural heritage.

Acknowledgement: This article was prepared as part of the project of the Center for Sociological Research of the Faculty of Philosophy, Niš titled Tradition, modernization and national identities in Serbia in the Balkans during the process of European integrations (179074), with the financial support of the Ministry of Education, Science and Technological Development of the Republic of Serbia. It was presented at the scientific conference "Tradition, modernization and identity IX: The role of the university community in the improvement of regional development and affirmation of the culture of peace in the Balkans", held at the Faculty of Philosophy, Nišs, on May 25, 2018.

\section{REFERENCES}

Bruell, Cornelia. Creative Europe 2014-2020, A New Programme - A New Cultural Policy as well?. Stuttgart: Institute for Cultural Foreign Relations, 2013.

Брујић, Марија. Европеизачија у Србији почетком ХХІ века: антрополошка анализа сочиокултурних промена у периоду евроинтеграција. Београд: Филозофски факултет Универзитета у Београду, Одељење за етнологију и антропологију, 2016. 
Brumman, Christoph. „Cultural Heritage“. In International Encyclopedia of Social \& Behavioral Sciences, edited by James D. Wright, 414 - 419. Amsterdam: Elsevier.

Calligaro, Oriane. „From 'European Cultural Heritage' to 'Cultural Diversity'? The Changing Core Values of European Cultural Policy“. Politique Européenne 3, 45 (2014): 60-85.

Dragićević Šešić, Milena i Branimir Stojković. Kultura: Menadžment, animacija, marketing. Beograd: Clio, 2011.

Evropska komisija. Objašnjena Evropska unija: Kultura i audiovizuelni mediji. Beograd: Delegacija Evropske unije u Republici Srbiji, 2007.

Gačanović, Ivana. Problem evropskog identiteta. Uvod u antropologiju Evropske unije. Beograd: Srpski genealoški centar i Odeljenje za etnologiju i antropologiju Filozofskog fakulteta u Beogradu, 2009.

Gavrilović, Ljiljana. Potraga za osobenošću: Izazovi i dileme unutar koncepta očuvanja i reprezentovanja nematerijalnog kulturnog nasleđa. Etnoantropološki problemi 6, 1 (2011): 221-234.

Gielen, Pascal. No Culture, no Europe: On the Foundation of Politics. Amsterdam: Valiz, 2015.

Gordon, Christopher. „Culture and the European Union in Global Context“. The Journal of Arts Management, Law, and Society 37, 1 (2007): 11-30.

Hafstein, Valdimar T. „Cultural Heritage“. In A Companion to Folklore, edited by R. Bendix and G. HasanRokem, 500-519. Oxford: Blackwell, 2012.

Hudson, Ray. „One Europe or Many? Reflections on Becoming European“. Transactions of the Institute of British Geographers 25, 4 (2000): 409-426.

Kant, Imanuel. Večni mir. Beograd i Valjevo: Gutenbergova Galaksija, 1995.

Крстић, Марија. „Социо-културни и историјско-политички чиниоци настанка уједињене Европе после II светског рата - ка антрополошкој анализи“. Антропологија 11, 3 (2011): 51-73.

Tsaliki, Liza. „The Construction of European Identity and Citizenship”. In Media and Cultural Policy in the European Union, edited by K. Sarikakis, 157-182. Amsterdam and New York: Rodopi, 2007.

Lowenthal, David. The Heritage Crusade and the Spoils of History. Cambridge: Cambridge University Press, 1998.

McDonald, Maryon. “'Unity in Diversity'. Some Tensions in the Construction of Europe". Social Anthropology 4, 1 (1996): 47-60.

McDonald, Maryon. "European Identity - an Anthropological Approach". In: Reflections on European Identity. Working Paper, ed. Thomas Jansen. European Commission, Forward Studies Unit, 77-80, 1999.

Milenković, Miloš. Antropologija multikulturalizma: Od politike identiteta ka očuvanju kulturnog nasleđa. Beograd: Odeljenje za etnologiju i antropologiju Filozofskog fakulteta u Beogradu i Srpski genealoški centar, 2014.

Миленковић, Милош. Повратак наслеђу: Оглед из примењене хуманистике. Београд: Филозофски факултет у Београду и Досије студио, 2016.

Moren, Edgar. Kako misliti Evropu. Sarajevo: Svjetlost, 1989.

Nic Craith, Máiréad. "Europe`s (Un)common Heritage(s)". Traditiones, 41, 2 (2012): 11-28.

Nic Craith, Máiréad. „Intangible Cultural Heritage. The Challenge for Europe“. Anthropological Journal of European Cultures 17, 1 (2008): 54-73.

Patel, Kiran, Klaus. The Cultural Policy of Europe. European Capitals of Culture and European Union since the 1980s. London: Routledge, 2012.

Petković, Jelena. "Multikulturalnost savremenih društava: između ostvarivanja i osporavanja demokratije". Kultura 160 (2018): 58-80.

Sassatelli, Monica. Becoming Europeans: Cultural Identity and Cultural Policies. Basingstoke and New York: Palgrave Macmillan, 2009.

Sassatteli, Monica. "Imagined Europe: The Shaping of a European Cultural Identity through EU Cultural Policy". European Journal of Social Theory 5, 4 (2002): 435-451.

Sen, Amartya. Development as Freedom. Oxford: Oxford University Press, 1999.

Shore, Cris. "Inventing the 'People's Europe': Critical Approaches to European Community 'Cultural Policy'". Man 28, 4 (1993): 779-800.

Shore, Cris and Marc Abélès. "Debating the European Union: An interview with Cris Shore and Marc Abélès". Anthropology Today 20, 2 (2004): 10-14.

Shore, Cris. "In uno plures' (?) EU Cultural Policy and the Governance of Europe. Cultural Policy and European Integration, Anthropological Perspective". Cultural Analysis 5 (2006): 7-26.

Skot-Hansen, Dorte. "Between Image and Identity: Holstebro as a Model for Cultural Policy". International Journal of Cultural Policy 5 (1998): 149-167.

Stojković, Branimir. Evropski kulturni identitet. Beograd: Službeni glasnik, 2008.

Stojković, Branimir. Kulturna politika evropske integracije: Evropska unija i Savet Evrope. Beograd: Institut za evropske studije, 1995.

Жикић, Бојан. Слике у излогу: културне представе о Европској унији као средство описивања паралелне стварности стағу у Србији 1991-2011. Београд: Одељење за етнологију и антропологију Филозофског факултета у Београду и Српски генеалошки центар, 2013. 


\section{INTERNET SOURCES}

Council of Europe 1954, European Cultural Convention. Accessed 21.04.2019. https://rm.coe.int/ CoERMPublicCommonSearchServices/DisplayDCTMContent?documentId=090000168006457e...

Council of Europe 1975, European Charter of the Architectural Heritage. Accessed 07.07.2019. 〈https://www.icomos.org/en/charters-and-texts/179-articles-en-francais/ressources/charters-andstandards/170-european-charter-of-the-architectural-heritages.

Council of Europe 1984, European Declaration on Cultural Objectives. Accessed 21.04.2019. «https://rm.coe.int/ CoERMPublicCommonSearchServices/DisplayDCTMContent?documentId=09000016806b23f1..

Council of Europe 2005, Council of Europe Framework Convention on the Value of Cultural Heritage for Society, Faro Convention. Posećeno 25.05.2019. 〈https://www.coe.int/en/web/conventions/full-list//conventions/rms/0900001680083746〉.

Council of Europe 2018, European Cultural Heritage Strategy for the 21st century. Posećeno 12.05.2019. 〈https://rm.coe.int/european-heritage-strategy-for-the-21st-century-strategy-21-full-text/16808ae270.〉.

Europa EU 2018, European Year of Cultural Heritage. Accessed 13.06.2019. 'https://europa.eu/culturalheritage/eych-events-grid_en>.

European Commission 2007, First-ever European strategy for culture: contributing to economic growth and intercultural understanding. Accessed 11.05.2019. «http://www.mondialisations.org/php/public/art.php?id= $26442 \& l a n=E N>$.

European Commission 2017, European Year of Cultural Heritage 2018. Accessed 14.06.2019. «http://europa. eu/rapid/press-release_MEMO-17-5066_en.htm〉.

European Commission 2018b, European Framework for Action on Cultural Heritage Factsheet. Posećeno 15. 06. 2019. 〈https://ec.europa.eu/culture/sites/culture/files/library/documents/2018_cult-eych_factsheet_framework_ def.pdf $>$.

European Commission 2018a, 10 European Initiatives. Accessed 15.06.2019. 〈https://ec.europa.eu/culture/ content/overview_en>.

Hugo, Victor. 1849. Speech to the International Peace Congress at Paris. Accessed 20.06.2019. «http://trove.nla. gov.au/newspaper/article/12914658.>.

Mattia, Julien. „Žuti prsluci: za četiri dana prikupljena milijarda za kamenje, a za sirotinju - ništa!“ Sputnik, 20. april 2019. Accessed 6.6.2019. https://rs.sputniknews.com/evropa/201904201119520375-zuti-prsluci-notr-dam/

UNESCO. 1972. The World Heritage Convention. Accessed 06.07.2019. https://whc.unesco.org/en/conventiontext/>.

UNESCO. 2018. Basic Texts of the 2003 Convention for the Safeguarding of the Intangible Cultural Heritage. Posećeno 19.09.2019. https://ich.unesco.org/doc/src/2003_Convention_Basic_Texts-_2018_version-EN.pdf

Vrgoč, Dubravka. „Kulturne raznolikosti jedina brana diktatu industrije zabave”, in: Vjesnik, Zagreb, 19. septembar 2003. Posećeno 03. septembra 2015. https://www.vecernji.hr/kultura/dubravka-vrgoc-na-celueuropske-kazalisne-konvencije-do-2015-633403.

\section{EVROPSKA KULTURNA POLITIKA: PRIORITETI I PRAKSA U OBLASTI KULTURNOG NASLEĐA}

Primenom komparativne metode $i$ analize dokumenata $u$ radu se istražuje promenjena pozicija $i$ uloga kulture kao delikatnog polja intervenisanja u oblasti evropskih integracionih politika. Na toj osnovi se pristupa sociokulturološkoj i antropološkoj analizi osnovnih pravaca razvoja evropske politike u oblasti kulture od početka procesa evropskih integracija do danas. Cilj istraživanja jeste da se ukaže na povode i posledice povećanog interesovanja evropske politicke agende za koncept kulturnog nasleđa, posebno od sedamdesetih godina 20. veka, sa intencijom da se kritički razmotre konceptualna tumačenja $i$ strateške upotrebe kulturnog nasleđa u okviru evropske kulturne politike. U tu svrhu, pruža se uvid u osnovne istraživačke nalaze o prioritetima i praksama u oblasti afirmacije kulturnog nasleđa Evrope, dobijenih analizom $i$ interpretacijom sekundarnih izvora podataka (naučnih publikacija, brojnih međunarodno priznatih dokumenata, različitih evropskih programa i projekata). Zaključuje se o svojevrsnoj protivrečnosti u retorici evropskih političkih aktera koja je u oblasti kulturnog nasleđa balansirala između evropskog partikularizma $i$ univerzalizma, kao $i$ o svojevrsnom strateškom pomeranju evropskih kulturnih akcija od primarne afirmacije simboličkog $i$ socijalnog potencijala kulturnog nasleđa ka sve naglašenijoj upotrebi i iskorišćavanju njegove ekonomske dimenzije.

Ključne reči: kultura, kulturno nasleđe, evropska kulturna politika, društveni razvoj. 